\title{
SPATIAL AND TEMPORAL VARIATION OF HIDROGEOCHEMISTRY AND KARST FLOW PROPERTIES TO CHARACTERIZE KARST DYNAMIC SYSTEM IN BRIBIN UNDERGROUND RIVER, GUNUNG KIDUL REGENCY, DIY PROVINCE
}

\section{Summary}

\section{Geography Study Program}

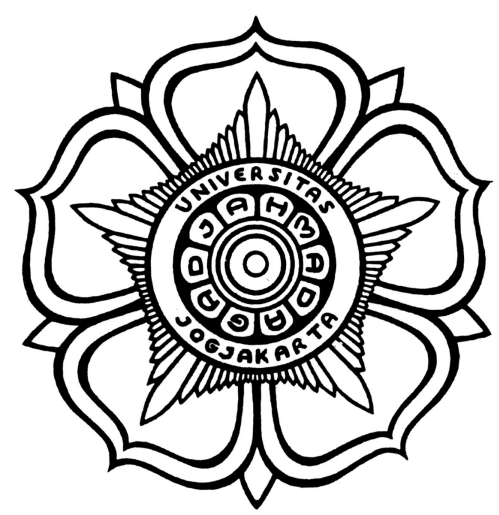

By:

Tjahyo Nugroho Adji 05/1729/PS

\section{GRADUATE SCHOOL FACULTY OF GEOGRAPHY GADJAH MADA UNIVERSITY \\ YOGYAKARTA \\ 2010}




\begin{abstract}
This research is conducted in karst area, which is particularly enclosed by Bribin Underground River Catchment, Gunungkidul Regency. The objectives of this study are: (1) to understand spatial and temporal variation of flow characteristic as well as Diffuse Flow Proportion (PAD) of Bribin River; (2) to assess hydrogeochemistry and to recognize the relationship between hydrogeochemistry and flow characteristics of Bribin River, and (3) to define water agressivity of Bribin River with respect to carbonate mineral and to express the components of Karst Dynamic System (KDS) one-year behavior.

To define flow characteristic and PAD, three water level data loggers are installed within upper, lower and the leakage point along Bribin River continued by discharge measurement with the purpose of attaining stage-discharge rating curve. Afterwards, PAD is defined by conducting digital filtering baseflow separation approach after calculation of diffuse, fissure, and conduit recession constant. Next, to figure out hydrogeochemical condition, 120 sample of karst water are analyzed including rain, underground-river, and drip water. After that, scatter plots between hydrogeochemical parameters are conducted to achieve the correlation between PAD and hydrogeochemistry as well as to figure out hydrogeochemical processes to occur. Subsequently, Saturation Indices analysis with respect to calcite mineral and KDS components correlation is carried out to define karst water agressivity and its manners along flowpath of Bribin River.

The research's result demonstrates that there is spatial and temporal differentiation of flow characteristics along Bribin River attributable to the comportment of karst aquifer toward discharging its diffuse, fissure, or conduit flow components, which consequence to the dissimilarity of PAD distribution along Bribin River. Accordingly, PAD characteristics result to dry season hydrogeochemical condition of Bribin River. However, wet season hydrogeochemical condition is more influenced by means of dilution by precipitation process within flood events, which exaggerates $\mathrm{CO}_{2}$ content of water. Generally, the upper-stream cave tend to more aggressive in dissolving limestone, contrast to down-steam cave that be inclined to precipitate carbonate mineral as a result of their differentiation of cavities configuration. In addition, down-stream cave is characterized by open system cavities, subsequent to the $\mathrm{CO}_{2}$ discharge to preserve dissolution process.
\end{abstract}

Keywords :Flow characteristic, diffuse, fissure, conduit, hydrogeochemistry, aggressivity 


\section{A. Introduction}

\section{Problem statement}

Karst Dynamic Systems (SKD) term introduced by Daoxian (2005) actually is not the new term. Previously, Bogli (1960, 1980), Sweeting (1972), Trudgill (1985), Ford and Williams (1992) had explained this word as a system that covers dynamic processes among $\mathrm{H}_{2} \mathrm{O}, \mathrm{CO}_{2}$, and $\mathrm{CaCO}_{3}$ controlled by the limestone aquifer environment. White (1988), Ford and Williams (1992), Smart and Hobbes (1986), as well as Gillieson (1996) principally divide the characteristics of karst aquifer flows into three components, i.e. conduit; fissure, and diffuse. Each part has different characteristic and resource that is highly associated with 4 major components of aquifer to recharge (White, 2004). Those are allogenic recharge, internal runoff, diffuse infiltration and perched aquifer overlying karst aquifer. Within karst aquifer, the major process to control characteristic and karst aquifer flow is dissolution. In addition, Dreybort and Gabrovsek (2003) states that the rate of dissolution process is highly correlated with the concentration level of $\mathrm{CO}_{2}$ within karst groundwater. Also, the type of conduit, whether it is open or close system, also controls the rate of dissolution process (Freeze and Cherry, 1979).

In general, the research to disclose the nature and characteristics of karst aquifer employs inductive approaches since the type of conduit is anisotropic. According to Mudry (2004), one of inductive approaches is hydrogeochemical method assuming that chemical constituents of karst groundwater reflect to the process inside karst aquifer. This method is typically collective with the nature of underground flow to acquire the most representative method, to describe the system of groundwater karst storage media and the flow nature of limestone aquifer that is correlated with chemical characteristics of karst groundwater (Liu, et al, 2004a and 2004b, Etfimi, 2005, Wang and Luo, 2001, Anthony, et al, 1997, as well as Raeisi and Karami, 1997). Martin et al. (2002) and Karimi et al. (2004) opine that beside the interaction between diffuse flow and conduit flow, it turns out that the aggressivity of karst groundwater also plays important role on fissure carbonate rock development. On the other hand, Taylor and Greene (2001) conclude that quantitative approach is needed to describe the characteristic of karst aquifer in detail.

Bribin Underground River (SBT Bribin) has high potency as the primary water resource to fulfill the need of domestic community at Gunungsewu Karst, Gunungkidul Regency. This area is famous as a water deficiency region due to the depth conduit 
system to be achieved. In 2004 to 2009, The Government of Gunungkidul cooperates with The Government of DIY Province, Ministry of Research and Technology, BATAN, Federal Misnistry and Education-Universitas Kalsruhe, Germany has finished to drill and to dam SBT Bribin to be used as micro-hydro systems. This dam is expected to produce 250 to $300 \mathrm{KW}$ of electricity to double the service capacity of groundwater distribution. However, the research on the nature of flow, karst aquifer and hydrogeochemical processes to control the development of SBT Bribin channel has not been conducted yet. Thus, some issues raise:

1. How are the SBT Bribin flow properties to release its karst flow components and its dependable flow (PAD) along the year?;

2. How is the relationship between hydrogeochemical condition and SBT Bribin karst flow properties?;

3. How is the SKD characteristic that is approached by aggressivity level to dissolve carbonate rock and its relationship to the SKD parameters along the year?

\section{Research objective}

The objectives of this research are as follows:

1. To analyze the spatial and temporal in terms of characteristic and PAD of SBT Bribin;

2. To evaluate the hydrogeochemical condition along SBT Bribin and to find its relationship with the karst flow nature;

3. To characterize SKD within SBT Bribin that is approached by aggressivity level to dissolve limestone and its relationship to SKD parameters during the year;

\section{B. Research Method}

This research uses inductive approach that is similar with Quasi-Experimental Research as a part of Experimental Research (Dane, 1990) because the nature of karst aquifer is anisotropic (permeability to every directions different)-the uncontrolled conduit. Also, no homogeny and gradual correlation between surface and underground surface is another reason that this research does not apply deductive approach.

In addition, the difficulty to survey the karst aquifer condition, such as the thickness of carbonate rock, the $\mathrm{CO}_{2}$ content within aquifer, the fissure network, and conduit on karst aquifer that can not be directly correlated with the condition of SBT 
Bribin, supports the using of the Quasi-Experimental Research to be applied in this research. The research design is Time Series Design of Quasi-Experimental Research, using Field- Survey Research Method.

\section{The materials and tools}

The principal materials is white and blank panchromatic aerial photo-scale 1:20.000 and 1:30.000 year 1992, 1993, and 1994, digital topographical map scale 1 : 25.000 year 2001, Gunungsewu karst underground river map by MacDonalds and Partners (1984), as well as LANDSAT and SRTM satellite image.

The major tools used in this research are stated below.

a. HOBO-water level data logger to record the SBT Bribin water level fluctuation

b. Current meter to measure the underground river discharge

c. Some tools to measure the field water quality parameters $(\mathrm{pH}, \mathrm{Eh}, \mathrm{EC}$, and temperature)

d. Water sampling tools

\section{The boundary of the research area}

The research area covers all rainfall catchments area of SBT Bribin. The boundary is based on MacDonalds and Partners (1984) that Bribin cave is assumed to be an outlet at the lower part of this river.

\section{Data}

The primary data in this research is discharge fluctuation of SBT Bribin during a year. The tools to record the water surface fluctuation are placed at 3 locations: Gilap Cave (upper course), Bribin Cave (under course), and Ngreneng Cave (leakage), for one year time period. During observation period, discharge measurement is conducted several times to get the data of minimum, average and maximum discharge. The data is needed to construct the stage discharge rating curve. During one year, the sample of 5 points along SBT Bribin is taken once a month. In period of rain season, the number of the sampling taken is adjusted with the flood hydrograph period to get sampling variation at normal, peak, and recession stage.

\section{Data analysis}

Some analyses are conducted in this research as follows. 
a. Spatial and temporal analysis of SBT Bribin flow components characteristic during one year that cover: (1)analysis of the relationship between underground river discharge and water level; (2)analysis of recession constant and hydrograph; (3)analysis of baseflow separation

b. Spatial and temporal variation analysis of hydrogeochemical and aggressivity of karst groundwater. This analysis consists of: (1)Charge Balance Error Calculation analysis; (2)Saturation Indices analysis; (3)partial carbon dioxide water pressure analysis

c. Analysis of SKD components behavior, correlation between components, and correlation with baseflow that consists of (1) monthly hydrogeochemical analysis; (2)hydrogeochemical analysis at peak hydrograph or flood events; (3) long-term and storm-scale hydrochemograph analysis; (4)correlation analysis of variation between hydrogeochemical with flow component characteristics; (5) behavior analysis of SKD indicator (parameter) on rain, drip water of speleothem and water of underground river and correlation analysis between water aggressivity with $\mathrm{pH}$, dissolved calcium, and partial carbondioxide pressure.

\section{Result and Analysis}

\section{Spatial and temporal characteristics of flow and PAD along SBT Bribin}

The flow and PAD characteristics along Bribin Underground River covers: (1) recession constant and flow hydrograph parameter; and (2) the baseflow percentage from Gilap Cave (upper course), Bribin Cave (under course) and Ngreneng Cave (leakage) in which the tools to record the fluctuation of water surface of underground river is installed.

\section{a. Recession constant $(K)$, time to peak $\left(T_{p}\right)$, and time to baseflow $\left(T_{b}\right)$}

The recession constant studied in this research is divided into 3 parts. Those are: (i) recession constant for conduit $\left(\mathrm{K}_{\mathrm{c}}\right)$; (ii) recession constant for fissure $\left(\mathrm{K}_{\mathrm{i}}\right)$; and (iii) recession constant for diffuse $\left(\mathrm{K}_{\mathrm{b}}\right)$. The comparison of recession constant among the three caves (Bribin, Gilap, and Ngreneng caves) describes the karst aquifer characteristics to release the water components inside the karst aquifer. The hydrograph parameter discussed in this research is time to peak $\left(T_{p}\right)$, that describes how fast the karst aquifer response to recharge the underground river, and time to baseflow $\left(\mathrm{T}_{\mathrm{b}}\right)$. The parameter index of the three caves along SBT Bribin is presented in Table 1. 
Table 1. Summary of Recession Constant and Flood Parameter at SBT Bribin

\begin{tabular}{|c|c|c|c|c|c|}
\hline Caves & $\mathbf{K}_{\mathbf{c}}$ & $\mathbf{K}_{\mathbf{i}}$ & $\mathbf{K}_{\mathbf{b}}$ & $\mathbf{T}_{\mathbf{p}}$ (hour) & $\mathbf{T}_{\mathbf{b}}$ (hour) \\
\hline Gilap & $\begin{array}{c}0.14-0.88 \\
\text { (avg=0.463) }\end{array}$ & $\begin{array}{l}0.39-0.92 \\
(\mathrm{avg}=0.767)\end{array}$ & $\begin{array}{c}0.94-0.99 \\
(\mathrm{avg}=0.996)\end{array}$ & $\begin{array}{c}1.5-5 \\
(\mathrm{avg}=3.03)\end{array}$ & $\begin{array}{c}7-192 \\
(\operatorname{avg}=36.7)\end{array}$ \\
\hline Bribin & $\begin{array}{l}0.02-0.519 \\
(\operatorname{avg}=0.332)\end{array}$ & $\begin{array}{c}0.002-0.95 \\
(\mathrm{avg}=0.825)\end{array}$ & $\begin{array}{c}0.98-0.99 \\
(\mathrm{avg}=0.998)\end{array}$ & $\begin{array}{c}2-9.5 \\
(\operatorname{avg}=5.5)\end{array}$ & $\begin{array}{c}5-192 \\
(\mathrm{avg}=36.3)\end{array}$ \\
\hline Ngreneng & $\begin{array}{c}0.188-0.748 \\
(\operatorname{avg}=0.333)\end{array}$ & $\begin{array}{c}0.732-0.971 \\
(\operatorname{avg}=0.877)\end{array}$ & $\begin{array}{c}0.978-0.999 \\
(\mathrm{avg}=0.992)\end{array}$ & $\begin{array}{l}2.5-7.5 \\
(\operatorname{avg}=4.5)\end{array}$ & $\begin{array}{c}9-240 \\
(\operatorname{avg}=16.8)\end{array}$ \\
\hline
\end{tabular}

$* \mathrm{~K}_{\mathrm{c}}=$ recession constant conduit $; \mathrm{K}_{\mathrm{i}}=$ recession constant fissure; $\mathrm{K}_{\mathrm{b}}=$ recession constant diffuse

$* \mathrm{~T}_{\mathrm{p}}=$ time to peak; $\mathrm{T}_{\mathrm{b}}=$ time to baseflow

Based on the Table 1, it turns out that the recession constant for diffuse, fissure, and conduit flows have variation. The highest average of diffuse flow recession constant is found at Bribin Cave (0.998) with a diminutive variation, indicates that the domination of diffuse flow after flood events on the short and long term period is still tremendous with a minimum discharge of 1600 lt/second. On the other hand, Gilap Cave has a slightly lower average of diffuse recession constant to Bribin's. The variation during flood season is significantly high (0.94-0.99) with 0.996 as the average. Next, the diffuse recession constant at Ngreneng caves has the lowest average (0.992). It designates that Ngreneng caves release the diffuse component faster compared to Bribin Cave and Gilap Cave. This fact is supported by the value of time to peak and time to baseflow (16.8 hours) compared to Gilap Cave and Bribin Cave, 36.7 hours and 36.3 hours, respectively.

Furthermore, the conduit recession constant shows that those three caves have a steep recession for below 0.5 during flood period. The lower recession constant the faster the release of conduit flow component (Schulz, 1976). Ngreneng Cave has a low average of $\mathrm{K}_{\mathrm{c}}(0.333)$ since within the rain peak period it accepts additional flow from sinkhole. Additionally, the $\mathrm{K}_{\mathrm{c}}$ at Ngreneng Cave is also affected by the flow from Bribin Cave (as a leakage point). Based on time to peak $\left(T_{p}\right)$, this cave should have similar period of time to reach flood peak as Bribin Cave. However, the research shows that the $T_{p}$ of Ngreneng Cave is one hour faster than Bribin Cave's due to its morphology as a sinkhole. Meanwhile, Gilap Cave that is located at the upper course has the highest $\mathrm{K}_{\mathrm{p}}$ and $\mathrm{T}_{\mathrm{p}}$ among other two caves.

On the other hand, the fissure recession constant $\left(\mathrm{K}_{\mathrm{i}}\right)$ for those three caves do not differ significantly with the range between 0.767 and 0.877 . Gilap Cave has the lowest $\mathrm{K}_{\mathrm{i}}$ (0.767), while Bribin Cave and Ngreneng Cave have parallel $\mathrm{K}_{\mathrm{i}}$ amounting at 0.825 and 0.877 , respectively. Table 1 explains that Gilap Cave has the fastest responds to rain ( $\mathrm{Tp}=3$ hours) due to its location at the upper of catchment area. The average $\mathrm{K}_{\mathrm{b}}$ 
of this cave is high enough (0.996) compared to Ngreneng Cave (0.992). Thus, Gilap cave is still in fine condition to release its water storage from karst aquifer.

Having the lowest $K_{b}$, Ngreneng Cave has relatively long period of time to peak (Tp) but a short period of time to baseflow $(\mathrm{Tb})$ for 16.8 hours. It indicates that the baseflow component diffused by aquifer is fast due to its function as a point recharge from the basin neighboring. This also proves that sinkhole has significant relationship with flood hydrograph parameter at Ngreneng Cave. The summary of flood hydrograph parameter and recession constant is shown below.

Table 2. Condition of Karst Aquifer Flow Component Based on Comparison of Flood Hydrograph Parameter

\begin{tabular}{|c|c|c|c|}
\hline $\begin{array}{l}\text { Hydrograph } \\
\text { Parameter }\end{array}$ & Caves & Comparison & Characteristics \\
\hline $\mathrm{K}_{\mathrm{b}}=0.996$ & \multirow{5}{*}{ Gilap } & $\begin{array}{l}>\text { Ngreneng } \\
<\text { Bribin }\end{array}$ & $\begin{array}{l}\text { - aquifer releases diffuse storage faster than Bribin, but slower than } \\
\text { Ngreneng } \\
\text { - Better diffuse flow storage (small fracture) than Ngreneng }\end{array}$ \\
\hline $\mathrm{K}_{\mathrm{i}}=0.767$ & & $\begin{array}{l}<\text { Ngreneng } \\
<\text { Bribin }\end{array}$ & - the fastest fissure storage releasing \\
\hline $\mathrm{K}_{\mathrm{c}}=0.463$ & & $\begin{array}{l}>\text { Ngreneng } \\
>\text { Bribin }\end{array}$ & $\begin{array}{l}\text { - the slowest conduit releasing by aquifer } \\
\text { - the smalest catchment area covered }\end{array}$ \\
\hline $\mathrm{T}_{\mathrm{p}}=3.03$ hour & & $\begin{array}{l}<\text { Ngreneng } \\
<\text { Bribin }\end{array}$ & - the shortest distance to reach flood peak (upper catchment) \\
\hline $\mathrm{T}_{\mathrm{b}}=36.7$ hour & & $\begin{array}{l}>\text { Ngreneng } \\
>\text { Bribin }\end{array}$ & $\begin{array}{l}\text { - aquifer releases diffuse storage in slow manner } \\
\text { - relatively poor conduit development compared to Bribin and } \\
\text { Ngreneng }\end{array}$ \\
\hline$K_{b}=0.998$ & \multirow{5}{*}{ Bribin } & $\begin{array}{l}>\text { Ngreneng } \\
>\text { Gilap }\end{array}$ & $\begin{array}{l}\text { - the best diffuse flow storage (slowest diffuse flow releasing by } \\
\text { aquifer) } \\
\text { - significant discharge within peak of dry season }\end{array}$ \\
\hline $\mathrm{K}_{\mathrm{i}}=0.825$ & & $\begin{array}{l}<\text { Ngreneng } \\
>\text { Gilap }\end{array}$ & - relatively abundant fissure storage (similar to Ngreneng) \\
\hline $\mathrm{K}_{\mathrm{c}}=0.332$ & & $\begin{array}{l}<\text { Ngreneng } \\
<\text { Gilap }\end{array}$ & $\begin{array}{l}\text { - the occurrence of point recharge to increase conduit recession } \\
\text { constant }\end{array}$ \\
\hline $\mathrm{T}_{\mathrm{p}}=5.5$ hour & & $\begin{array}{l}>\text { Ngreneng } \\
>\text { Gilap }\end{array}$ & - the largest catchment area covered \\
\hline $\mathrm{T}_{\mathrm{b}}=36.3$ hour & & $\begin{array}{l}>\text { Ngreneng } \\
<\text { Gilap }\end{array}$ & $\begin{array}{l}\text { - the domination both conduit and diffuse flow components within flood } \\
\text { events } \\
\text { - the slowest diffuse flow component }\end{array}$ \\
\hline $\mathrm{K}_{\mathrm{b}}=0.992$ & \multirow{5}{*}{ Ngreneng } & $\begin{array}{l}<\text { Gilap } \\
<\text { Bribin }\end{array}$ & - the fastest diffuse flow component releasing by aquifer \\
\hline $\mathrm{K}_{\mathrm{i}}=0.877$ & & $\begin{array}{l}>\text { Gilap } \\
>\text { Bribin }\end{array}$ & - the slowest fissure flow component releasing by aquifer \\
\hline $\mathrm{K}_{\mathrm{c}}=0.333$ & & $\begin{array}{l}<\text { Gilap } \\
>\text { Bribin }\end{array}$ & $\begin{array}{l}\text { - cave entrance as apoint recharge to overland flow } \\
\text { - leakage og Bribin main channel }\end{array}$ \\
\hline $\mathrm{T}_{\mathrm{p}}=4.5$ hour & & $\begin{array}{l}>\text { Gilap } \\
<\text { Bribin }\end{array}$ & $\begin{array}{l}\text { - influenced by overlandflow characteristic within flood events to } \\
\text { shorten } T_{p}\end{array}$ \\
\hline $\mathrm{T}_{\mathrm{b}}=16.8$ hour & & $\begin{array}{l}<\text { Gilap } \\
<\text { Bribin }\end{array}$ & $\begin{array}{l}\text { - the fastest releasing diffuse flow component } \\
\text { - development of conduit cavities }\end{array}$ \\
\hline
\end{tabular}

$* \mathrm{~K}_{\mathrm{c}}=$ recession constant conduit $; \mathrm{K}_{\mathrm{i}}=$ recession constant fissure $; \mathrm{K}_{\mathrm{b}}=$ recession constant diffuse

$* \mathrm{~T}_{\mathrm{p}}=$ time to peak; $\mathrm{T}_{\mathrm{b}}=$ time to baseflow 
According to Table 2, it seems the river at Bribin Cave performs the most significant baseflow storage and confirms the slowest releasing compared to Ngreneng and Gilap Caves. The upper point within catchment at SBT Bribin, represented by Gilap Cave, has a slow baseflow release that graciously contributes to the sustainability of SBT Bribin discharge within dry season. Due to its position at upper course, nevertheless, it has the fastest response to flood and low discharge within dry season. In addition, Ngreneng Cave has different characteristics. Although it is a leakage from and located closed to SBT Bribin, it performs different aquifer releasing characteristics from Bribin's due to its entrance morphology as a recharge point for some karst basins surrounding.

\section{b. Baseflow Percentage (PAD)}

PAD is a ratio of baseflow discharge separated from flood hydrograph and total flow. Usually, it is used widely to characterize a water storage or aquifer potency to recharge underground river during the year. Table 3 and Figure 1 below show the PAD distribution along SBT Bribin.

Tabel. 3. PAD Condition along SBT Bribin

\begin{tabular}{|c|l|r|r|r|c|}
\hline \multirow{2}{*}{ NO } & \multicolumn{1}{|c|}{ Month } & \multicolumn{3}{|c|}{ PAD (\%) } & SEASON \\
& & GILAP & BRIBIN & NGRENENG & \\
\hline 1 & May 2006 & 80.41 & 97.03 & 80.35 & dry \\
\hline 2 & June 2006 & 80.47 & 98.40 & 80.36 & dry \\
\hline 3 & July 2006 & 80.93 & 98.53 & 80.37 & dry \\
\hline 4 & Augustus 2006 & 81.66 & 98.64 & 80.38 & dry \\
\hline 5 & September 2006 & 81.77 & 98.70 & 80.38 & dry \\
\hline 6 & October 2006 & 82.09 & 99.14 & 80.38 & dry \\
\hline 7 & November 2006 & 82.36 & 99.40 & 80.38 & dry \\
\hline 8 & December 2007 & 80.11 & 97.44 & 81.78 & wet \\
\hline 9 & January 2007 & 84.86 & 98.87 & 82.93 & wet \\
\hline 10 & February 2007 & 77.49 & 97.22 & 83.48 & wet \\
\hline 11 & March 2007 & 82.94 & 97.07 & 82.41 & wet \\
\hline 12 & April 2007 & 82.85 & 98.26 & 81.78 & wet \\
\hline
\end{tabular}

Sumber : data analysis (2006-2007)

Generally, monthly baseflow ratios at the three caves show a similar pattern. Initially, it increases gradually to achieve crest value within the peak of dry season. Afterward, it tends to fluctuate at rainy season by having a lower ratio since it is affected by the increasing conduit flow contribution. Along flowpath of SBT Bribin, the PAD is always augment (Bribin>Gilap). In this case, Bribin has the highest PAD 
(around 95\%) among Ngreneng and Gilap Caves (around 80\%). Interestingly, the monthly PAD pattern at Ngreneng Cave tends to increase, while it tends to decrease at Gilap and Bribin Caves. This fact supports the previous argument that due to the cave entrance as a sinkhole, it appears that the monthly average PAD increases. On the other hand, the percentage of baseflow for all caves tends to decline in flood period, indicates immense additional conduit flow to append (Table 4).

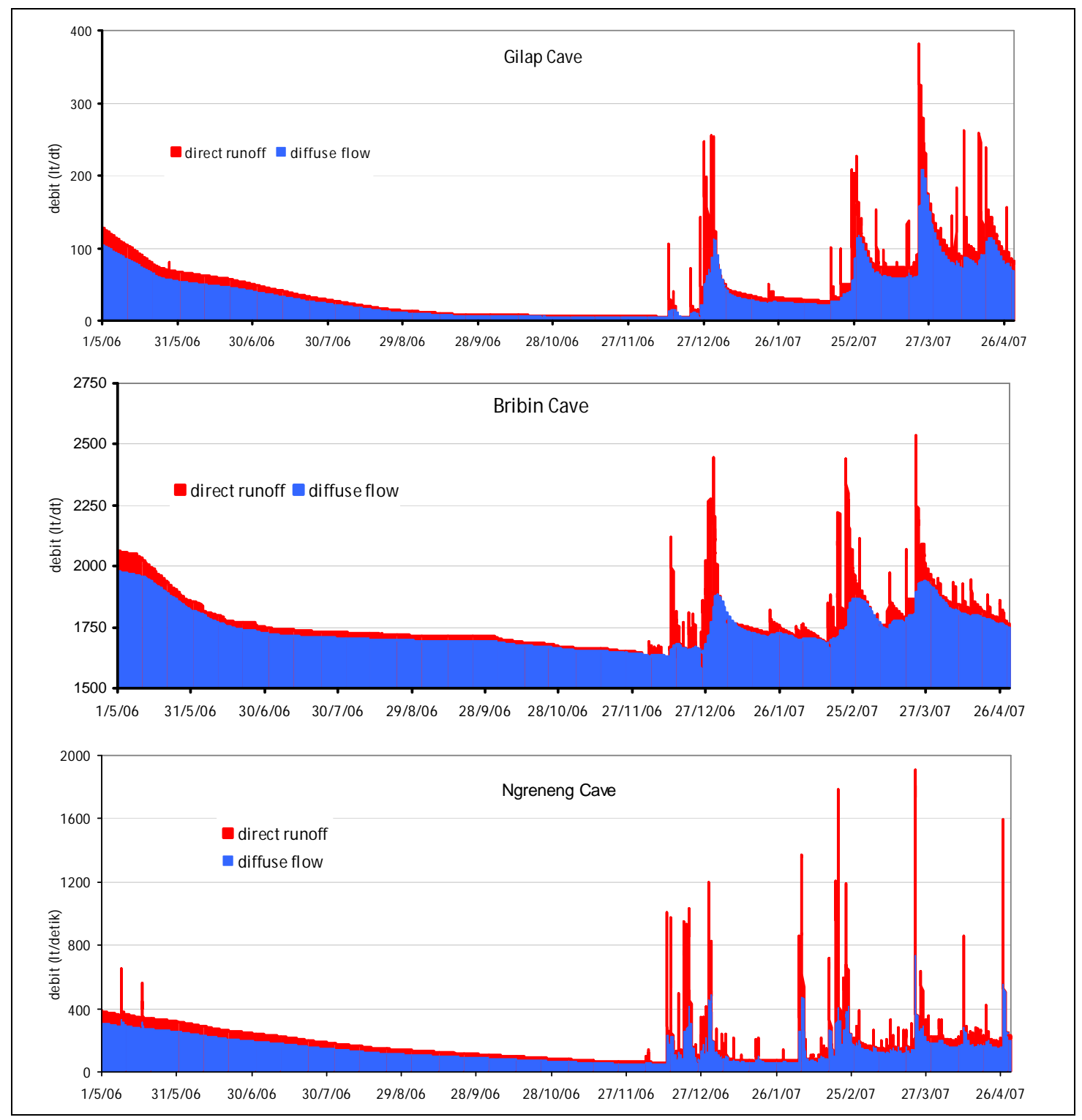

Figure 1. Baseflow Separation of SBT Bribin

According to the above table, Ngreneng Cave has the lowest PAD amounting at $46.5 \%$. It shows that the addition of diffuse flow within flood events is significantly 
lower than the conduit flow addition. Next, Bribin cave encompasses similar PAD compared to its monthly average. It indicates that PAD domination is better than other caves. Meanwhile, the Gilap cave's flood event average PAD is lower than its monthly average $(65.41 \%)$ but it is more significant compared to Ngreneng Cave. This shows that the conduit fracture pattern at Gilap cave does not develop as Ngreneng Cave yet.

Table. 4. Baseflow Ratio and Total Flow in Flood Period

\begin{tabular}{|c|c|c|c|c|c|c|c|}
\hline \multirow{2}{*}{ NO } & \multicolumn{2}{|c|}{ GILAP CAVE } & \multicolumn{3}{|c|}{ BRIBIN CAVE } & \multicolumn{2}{|c|}{ NGRENENG CAVE } \\
\hline & TIME FLOODING & PAD (\%) & TIME FLOODING & PAD & $(\%)$ & TIME FLOODING & PAD (\%) \\
\hline 1 & $13 / 12 / 06$ at $19: 00$ & 45.08 & $6 / 12 / 06$ at $22: 30$ & & 98.38 & $13 / 12 / 06$ at $19: 30$ & 41.43 \\
\hline 2 & $22 / 12 / 06$ at $15: 30$ & 55.52 & $7 / 12 / 06$ at $23: 00$ & & 99.02 & $15 / 12 / 06$ at $18: 30$ & 44.68 \\
\hline 3 & $31 / 12 / 06$ at $06: 30$ & 57.75 & $13 / 12 / 06$ at $19: 30$ & & 86.16 & $18 / 12 / 06$ at $13: 30$ & 50.85 \\
\hline 4 & $16 / 2 / 07$ at $16: 30$ & 57.25 & $29 / 12 / 06$ at $00: 30$ & & 77.72 & $20 / 12 / 06$ at $18: 30$ & 43.88 \\
\hline 5 & $24 / 2 / 07$ at $19: 00$ & 51.25 & $30 / 12 / 06$ at $17: 00$ & & 82.69 & $22 / 12 / 06$ at $20: 30$ & 44.68 \\
\hline 6 & $26 / 2 / 07$ at $18: 00$ & 58.55 & $16 / 2 / 07$ at $18: 00$ & & 92.29 & $5 / 2 / 07$ at $17: 00$ & 45.68 \\
\hline 7 & $6 / 3 / 07$ at $21: 00$ & 79.91 & $22 / 2 / 07$ at $21: 00$ & & 81.81 & $19 / 2 / 07$ at $20: 30$ & 40.79 \\
\hline 8 & $9 / 3 / 07$ at $19: 00$ & 78.18 & $23 / 2 / 07$ at $20: 00$ & & 84.51 & $20 / 2 / 07$ at $20: 00$ & 59.77 \\
\hline 9 & $14 / 3 / 07$ at $02: 00$ & 78.92 & $28 / 2 / 07$ at $01: 30$ & & 89.91 & & \\
\hline 10 & 19/3/07 at 00:00 & 72.75 & 7/3/07 at 05:00 & & 99.05 & & \\
\hline 11 & 21/3/07at 08:00 & 77.20 & $7 / 4 / 07$ at $22: 00$ & & 95.50 & & \\
\hline 12 & $23 / 3 / 07$ at $08: 00$ & 50.88 & $27 / 4 / 07$ at $20: 00$ & & 97.25 & & \\
\hline 13 & $7 / 4 / 07$ at $01: 30$ & 70.33 & & & & & \\
\hline 14 & $10 / 4 / 07$ at $18: 00$ & 62.94 & & & & & \\
\hline 15 & $11 / 4 / 07$ at $15: 00$ & 76.30 & & & & & \\
\hline 16 & $16 / 4 / 07$ at $23: 30$ & 73.80 & & & & & \\
\hline & Average & 65.41 & & & 90.36 & & 46.47 \\
\hline
\end{tabular}

Source : data analisis 2006-2007

\section{Hydrogeochemical spatial-temporal characteristics and its relationship with the SBT Bribin flow condition}

\section{a. The Relationship of EC-Calcium and EC-Bicarbonate}

Bribin cave that is located at the under course has the strongest relationship and the highest EC and dissolved Calcium-Bicarbonate among other caves within dry season. Based on the baseflow characteristic, Bribin Cave encompasses the highest baseflow and exposes the lowest baseflow fluctuation among other caves, amounting at approximately $98 \%$ and $\mathrm{K}_{\mathrm{b}}$ at 0.998 , while it is only $81 \%$ found at Gilap Cave. Ngreneng cave as a leakage of Bribin Cave (MacDonalds and Patners, 1984) has similar correlation, EC and calcium-bicarbonate as Bribin's.At upper course, other caves have lower correlation but Pentung River due to its baseflow contributed by non-karstic 
aquifer. Thus, the correlation is affected only by water-rock interaction process. The low correlation at Luweng Jomblangan is more affected by the mixing process between Pentung River and karst aquifer baseflow that has different interaction stage with carbonate rock. On the other hand, at Gilap Cave, the water-rock interaction process is not as intensive as found at Bribin and Ngreneng caves due to its high fissure flow. On rainy season, Bribin, Ngreneng, and Gilap caves have low Calcium-EC correlation; even it is lower than it in dry season. Table 6 shows that Gilap Cave has a negative correlation as a result of its lower PAD than other caves. Interestingly, Luweng Jomblangan has different pattern. It has high correlation on rainy season that may due to low conduit flow at upper course and the intermittent input from Pentung River (the direct runoff disappears after rainfall events).

Table 5. $\mathrm{R}^{2}$ Value of EC vs Calcium and Bicarbonate of SBT Bribin in Dry Season

\begin{tabular}{|c|c|c|c|c|c|c|}
\hline SITE & POSITION & $\mathrm{Ca}^{2+} \mathrm{VS} \mathrm{EC}$ & $\mathrm{HCO}_{3}^{-} \mathrm{VS} \mathrm{EC}$ & CORRELATION & $\begin{array}{l}\text { HYDROGEOCHEMICAL } \\
\text { PROCESSES }\end{array}$ & NOTE \\
\hline Pentung & Inlet & 0,878 & 0,596 & $\begin{array}{l}\text { Positive- high- } \\
\text { medium }\end{array}$ & $\begin{array}{l}\text { Water-rock interaction with } \\
\text { respect to non-carbonate rock }\end{array}$ & $\begin{array}{l}\text { The river with } \\
\text { baseflow input from } \\
\text { volcanic aquifer }\end{array}$ \\
\hline L. Jomblangan & upper & 0,364 & 0,687 & $\begin{array}{l}\text { Positive-low- } \\
\text { medium }\end{array}$ & $\begin{array}{l}\text { Mixing between carbonate and } \\
\text { non-carbonate water }\end{array}$ & $\begin{array}{l}\text { Direct overland flow } \\
\text { from Pentung }\end{array}$ \\
\hline G. Gilap & $\begin{array}{l}\text { Upper- } \\
\text { centre }\end{array}$ & 0,436 & 0,744 & Positive- low - high & $\begin{array}{l}\text { PAD slightly lower than Bribin } \\
\text { and Ngreneng, strong water- } \\
\text { rock interaction with respect to } \\
\text { carbonate rock }\end{array}$ & $\begin{array}{l}\text { PAD around } 80 \% \text {, } \\
\text { low } \mathrm{K}_{\mathrm{i}} \text { and high } \mathrm{K}_{\mathrm{c}}\end{array}$ \\
\hline G. Bribin & under & 0,892 & 0,867 & Positive-high & $\begin{array}{l}\text { The highest PAD, strongest } \\
\text { water-rock interaction with } \\
\text { respect to carbonate rock }\end{array}$ & $\begin{array}{l}\text { PAD around } 90 \%, \mathrm{~K}_{\mathrm{b}} \\
\text { high }\end{array}$ \\
\hline G. Ngreneng & leakage & 0,770 & 0,901 & Positive-high & $\begin{array}{l}\text { High PAD, located adjacent to } \\
\text { Bribin Cave, strong water-rock } \\
\text { interaction with respect to } \\
\text { carbonate rock }\end{array}$ & $\begin{array}{l}\text { PAD similar to } \\
\text { Bribin, with } K_{c} \text { low }\end{array}$ \\
\hline
\end{tabular}

\section{b. The relationship of discharge and PAD}

Karimi, et al. (2003) explains that recession period (when discharge decline after period of flood) cause the diffuse flow component increases and changes the chemical composition of karst underground river. Consequently, the PAD increases when the discharge decreases. The phenomenon at Gilap, Bribin and Ngreneng and all caves along SBT Bribin supports this theory. All those caves have significant negative correlation between discharge and PAD, especially in dry season. Pentung River (volcanic aquifer) has the strongest correlation because the discharge in dry season is filled by baseflow only. On the other hand, underground river correlation $\left(\mathrm{R}^{2}\right)$ is slightly lower than Pentung's since the residual river component is a combination between fissure and diffuse. The high correlation $\left(\mathrm{R}^{2}\right)$ at Gilap, Bribin, and Ngreneng caves are also affected by how fast the karst aquifer release the fissure flow $\left(\mathrm{K}_{\mathrm{i}}\right)$, as shown at Table 7. It is concluded that the higher the $\mathrm{K}_{\mathrm{i}}$, the lower correlation of discharge-PAD as Bribin shows. 
Table 6. $\mathrm{R}^{2}$ Value of EC vs Calcium and Bicarbonate of SBT Bribin in Wet Season

\begin{tabular}{|c|c|c|c|c|c|c|}
\hline SITE & POSITION & $\mathrm{Ca}^{2+} \mathrm{VS} \mathrm{EC}$ & $\mathrm{HCO}_{3}{ }^{-} \mathrm{VS} \mathrm{EC}$ & CORRELATION & $\begin{array}{c}\text { HYDROGEOCHEMICAL } \\
\text { PROCESSES }\end{array}$ & NOTE \\
\hline Pentung & Inlet & 0.013 & 0.311 & Positive-low & Low water rock interaction & $\begin{array}{l}\text { Large direct runoff in } \\
\text { flood events }\end{array}$ \\
\hline L. Jomblangan & upper & 0.812 & 0.889 & Positive-low & $\begin{array}{l}\text { Domination of diffuse flow due } \\
\text { to its position within karst } \\
\text { boundary (mixing) }\end{array}$ & $\begin{array}{l}\text { Visually. no strong } \\
\text { discharge fluctuation } \\
\text { along the year }\end{array}$ \\
\hline G. Gilap & $\begin{array}{l}\text { Upper- } \\
\text { centre }\end{array}$ & 0.020 & 0.071 & Negative-low & $\begin{array}{l}\text { High conduit contribution, } \\
\text { lowest PAD, low water rock } \\
\text { interaction }\end{array}$ & $\begin{array}{l}\text { Average } \mathrm{PAD}=73 \% \\
\mathrm{~T}_{\mathrm{b}}=36.7 \text { hour }\end{array}$ \\
\hline G. Bribin & under & 0.272 & 0.374 & Positive-low & $\begin{array}{l}\text { High conduit contribution, very } \\
\text { well diffuse storage }\end{array}$ & $\begin{array}{l}\text { Average } \mathrm{PAD}=94 \% \\
\mathrm{~T}_{\mathrm{b}}=36.3 \text { hour }\end{array}$ \\
\hline G. Ngreneng & leakage & 0.370 & 0.810 & Positive low-high & $\begin{array}{l}\text { Similar to Bribin, with faster } \\
\text { time to base flow }\left(T_{b}\right) \text { due to its } \\
\text { entrance cave's morphology }\end{array}$ & $\begin{array}{l}\text { Average } \mathrm{PAD}=88 \% \\
\mathrm{~T}_{\mathrm{b}}=16.8 \text { hour }\end{array}$ \\
\hline
\end{tabular}

Tabel 7. $\mathrm{R}^{2}$ Value of PAD vs. Discharge of SBT Bribin in Dry Season

\begin{tabular}{|c|c|c|c|c|}
\hline SITE & POSITION & $\begin{array}{c}\text { DISCHARGE } \\
\text { VS PAD }\end{array}$ & CORRELATION & NOTE \\
\hline Pentung & Inlet & 0.988 & Negative-high & $\begin{array}{l}\text { Highest correlation, filled by } 100 \% \text { baseflow from non- } \\
\text { karstic aquifer }\end{array}$ \\
\hline G. Gilap & $\begin{array}{l}\text { Upper- } \\
\text { centre }\end{array}$ & 0.852 & Negative-high & $\begin{array}{l}\text { High correlation, baseflow contributed by diffuse and } \\
\text { fissure flow. Correlation valued affected by fissure storage } \\
\text { releasing. } \mathrm{K}_{\mathrm{i}} \text { value in Gilap=0.767 }\end{array}$ \\
\hline G. Bribin & under & 0.855 & Negative-high & High correlation. $\mathrm{K}_{\mathrm{i}}$ value in Bribin $=0.332$ \\
\hline G. Ngreneng & leakage & 0.791 & Negative-high & Slightly low correlation,. $\mathrm{K}_{\mathrm{i}}$ value in Ngreneng $=0.877$ \\
\hline
\end{tabular}

Conversely, in wet season, the correlation declines and reaches a very low amount at Ngreneng and Gilap Caves due to the high fluctuation of PAD. The PAD fluctuation ranges from $45-80 \%$ at Gilap Cave, while it is $40-60 \%$ at Ngreneng Cave. However, Bribin Cave confirms different condition with PAD fluctuation between 80$90 \%$. The wet season correlation comparison of PAD-discharge along SBT Bribin is clearly presented in Table 8.

Table 8. $\mathrm{R}^{2}$ Value of PAD vs. Discharge of SBT Bribin in Wet Season

\begin{tabular}{|l|c|c|c|l|}
\hline \multicolumn{1}{|c}{ SITE } & \multicolumn{1}{|c|}{ POSITION } & $\begin{array}{c}\text { DISCHARGE } \\
\text { VS PAD }\end{array}$ & CORRELATION & \multicolumn{2}{c|}{ NOTE } \\
\hline Pentung & Inlet & 0.815 & Negative-high & $\begin{array}{l}\text { Stable baseflow in wet season, flash flooding behavior only } \\
\text { little decrease the dry season correlation }\end{array}$ \\
\hline G. Gilap & $\begin{array}{l}\text { Upper- } \\
\text { centre }\end{array}$ & $\mathbf{0 . 0 1 4}$ & Negative-very low & High fluctuation of baseflow (45-80\%) \\
\hline G. Bribin & under & $\mathbf{0 . 9 1 3}$ & Negative-high & Stable fluctuation of baseflow in flood events (80-90\%) \\
\hline G. Ngreneng & leakage & $\mathbf{0 . 0 1 1}$ & Negative-low & $\begin{array}{l}\text { High fluctuation of baseflow (40-65\%). High conduit } \\
\text { contribution due to its entrance cave's morphology }\end{array}$ \\
\hline
\end{tabular}

\section{c. The PAD-calcium and PAD-bicarbonate correlation}

In the dry season, there are significant differences on PAD-Calcium correlation of upper and lower part of caves along SBT Bribin. As a dissolved cation in underground river, the Calcium dissolved constituent is much affected by the PAD contribution. Bribin and Ngreneng caves have a similar PAD-Calcium and PAD- 
Bicarbonate correlation amounting at 0.73 and more than 0.85 , respectively. The similar amount of correlation for those caves may be caused by part of flow component of Ngreneng Cave comes from Bribin Cave.

Pentung River encompasses low PAD-Calcium correlation (0.352) because the water source is not primarily derived from karst aquifer. Hence, Calcium is not a dominant cation when baseflow dominates Pentung River. However, it performs high correlation of PAD-Bicarbonate because the bicarbonate ion can be originated as of some minerals but Calcite. On the other hand, Gilap Cave presents medium PADcalcium correlation (0.588) because of its position at upper course. Subsequently, the baseflow has shorter time to baseflow to dissolved Calcium as experienced by under course caves. Additionally, Gilap Cave has a quicker baseflow releasing compared to Bribin Cave. In summary, the correlation of PAD-Calcium and Bicarbonate comparison of caves along SBT Bribin is illustrated in Table 9.

Tabel 9. $\mathrm{R}^{2}$ Value of PAD vs. Calcium and Bicarbonate of SBT Bribin in Dry Season

\begin{tabular}{|c|c|c|c|c|c|c|}
\hline SITE & POSITION & $\mathrm{Ca}^{2+}$ VS EC & $\mathrm{HCO}_{3}^{-} \mathrm{VS} \mathrm{EC}$ & CORRELATION & $\begin{array}{l}\text { HYDROGEOCHEMICAL } \\
\text { PROCESSES }\end{array}$ & NOTE \\
\hline Pentung & Inlet & 0.352 & 0.985 & Positive-low-high & $\begin{array}{l}\text { Water-rock interaction with } \\
\text { respect to non-carbonate rock }\end{array}$ & $\begin{array}{l}\text { High correleation of } \\
\text { PAD-Bicarbonate as } \\
\text { derives from non- } \\
\text { carbonate aquifer }\end{array}$ \\
\hline G. Gilap & $\begin{array}{l}\text { Upper- } \\
\text { centre }\end{array}$ & 0.588 & 0.855 & $\begin{array}{c}\text { Positive-medium- } \\
\text { high }\end{array}$ & $\begin{array}{l}\text { Water-rock interaction with } \\
\text { respect to non-carbonate rock in } \\
\text { short time residence }\end{array}$ & $\begin{array}{l}\text { The shortest time } \\
\text { residence of baseflow, } \\
\text { low } K_{\mathrm{b}} \text { value rendah } \\
\text { with medium } \\
\text { contribution of fissure } \\
\text { flow }\end{array}$ \\
\hline G. Bribin & under & 0.730 & 0.892 & Positive- high & $\begin{array}{l}\text { Water-rock interaction with } \\
\text { respect to non-carbonate rock in } \\
\text { long time residence }\end{array}$ & High $K_{b}$ value \\
\hline G. Ngreneng & leakage & 0.730 & 0.941 & Positive- high & $\begin{array}{l}\text { Water-rock interaction with } \\
\text { respect to non-carbonate rock in } \\
\text { long time residence, and } \\
\text { influenced from Bribin flow (as } \\
\text { a leakage) }\end{array}$ & $\begin{array}{l}\text { Adjacent location to } \\
\text { Bribin }\end{array}$ \\
\hline
\end{tabular}

In wet season, the relationship between Calcium-Bicarbonate and PAD generally decreases due to the high supply of conduit flow. Additionally, Ngreneng Cave and Pentung River perform negative correlation due to the increasing constituent of Calcium or Bicarbonate as PAD inclines. Those location, indeed, have special characteristics. Pentung River as surface stream, hence the dissolved Calcium is not always foremost in the water. Ngreneng Cave, as previously mentioned, is a sinkhole at the base of karst valley that always catches fast conduit flow since the $\mathrm{K}_{\mathrm{c}}$ value is low in rainy season. On the other hand, Gilap Cave confirms the most stable correlation of Calcium andbBcarbonate with PAD compared to Bribin's and Ngreneng's. These facts are supported by its location that is adjacent to upper course that presents dominant fissure 
flow $\left(\mathrm{K}_{\mathrm{i}}\right)$. In addition, it has the most stable Kc among other caves so its content is relatively similar with diffuse flow (see Table 10).

Tabel 10. $\mathrm{R}^{2}$ Value of PAD vs. Calcium and Bicarbonate of SBT Bribin in Wet Season

\begin{tabular}{|c|c|c|c|c|c|c|}
\hline SITE & POSITION & $\mathrm{Ca}^{2+} \mathrm{VS} \mathrm{EC}$ & $\mathrm{HCO}_{3}{ }^{-} \mathrm{VS} \mathrm{EC}$ & CORRELATION & $\begin{array}{l}\text { HYDROGEOCHEMICAL } \\
\text { PROCESSES }\end{array}$ & NOTE \\
\hline Pentung & Inlet & 0.080 & 0.207 & $\begin{array}{l}\text { Negative-low } \\
\text { Positive-low }\end{array}$ & $\begin{array}{l}\text { Mixing between water-rock } \\
\text { interaction in non-carbonate } \\
\text { aquifer and overland flow. } \\
\text { Faster overland flow respond } \\
\text { than underground river. } \\
\text { (Tb=short). }\end{array}$ & Non-karstic aquifer. \\
\hline G. Gilap & $\begin{array}{l}\text { Upper- } \\
\text { centre }\end{array}$ & 0.690 & 0.628 & Positive-medium & $\begin{array}{l}\text { Strong fissure flow and stable } \\
\left(\mathrm{K}_{\mathrm{F}}=\text { high), slow conduit flow }\right. \\
\text { escalating within flood events } \\
\left(\mathrm{K}_{\mathrm{c}} \text { high). Strongest water-rock }\right. \\
\text { interaction process }\end{array}$ & $\begin{array}{l}\text { Shortest time of residence } \\
\text { of diffuse flow to dissolve } \\
\text { carbonate rock. Sloe aquifer } \\
\text { to release conduit storage } \\
\text { lain }\left(\mathrm{K}_{\mathrm{c}} \text { high). }\right.\end{array}$ \\
\hline G. Bribin & under & 0.143 & 0.149 & Positive- low & $\begin{array}{l}\text { The contribution of conduit flow } \\
\text { (dilution by precipitation } \\
\text { process) }\end{array}$ & $\begin{array}{l}\text { Diffrent diffuse flow and } \\
\text { conduit flow due to its } \\
\text { under-course position }\end{array}$ \\
\hline G. Ngreneng & leakage & 0.882 & 0.253 & Negative- high-low & $\begin{array}{l}\text { High conduit flow contribution } \\
\text { and Low } \mathrm{K}_{\mathrm{c}} \text { value to generate } \\
\text { dilution by precipitation } \\
\text { domination }\end{array}$ & $\begin{array}{l}\text { High conduit contribution } \\
\text { due to its entrance cave's } \\
\text { morphology }\end{array}$ \\
\hline
\end{tabular}

Based on the spatial and temporal analysis of hydrochemical parameter correlation and flow condition along SBT Bribin, it turns out that:

(1) In dry season, there is significant correlation between PAD (diffuse flow) with the level of the dominant constituent of karst water). The high correlation between EC and the dissolved constituent indicates the strong water-rock interaction processes (Desmarais and Rojstaczer, 2002). The fact that there is high correlation between PAD and the dissolved part supports the relation between hydrogeochemical and PAD contribution. Furthermore, the correlation is also affected by its spatial position by the side of Bribin cacthment area and the level of $\mathrm{K}_{\mathrm{b}}, \mathrm{K}_{\mathrm{i}}$ and $\mathrm{Kc}$.

(2) In wet season, hydrogeochemical processes moves from water-rock interaction process to dilution by precipitation since there is a high rain supply through conduit. The decline of PAD-dominant dissolved constituent and also ECdominant dissolved constituent correlations support the hydrochemical process movement. As previously explained, the spatial position and baseflow characteristic also affect the hydrogeochemistry of underground river.

3. Spatial and temporal karst water aggressiveness condition of limestone and its relationship with SKD condition along SBT Bribin.

a. The water aggressiveness level of SBT Bribin

According to Vesper and White (2004), the aggressiveness level on karst region is usually stated in an index known as Saturation Indices (SI) with respect to calcite 
mineral. The spatial and temporal distribution of SI along SBT Bribin is presented in Table 11.

Table 11. SI Distribution along SBT Bribin

\begin{tabular}{|l|l|c|c|c|c|c|}
\hline \multicolumn{1}{|c|}{ LOCATION } & \multicolumn{1}{|c|}{ POSITION } & DRY SEASON & \multicolumn{1}{c|}{ CONDITION } & WET SEASON \\
\hline Pentung & Inlet & -0.01 to 1.13 & $\begin{array}{c}\text { almost saturated to } \\
\text { super saturated }\end{array}$ & $\begin{array}{c}0.18 \text { to }-0.61 \\
\text { very aggressive to } \\
\text { saturated }\end{array}$ & 0.06 to -1.04 & $\begin{array}{c}\text { saturated to } \\
\text { aggressive }\end{array}$ \\
\hline Jomblangan & Upper & -0.43 to 0.63 & -0.15 to 1.18 & $\begin{array}{c}\text { aggressive to super } \\
\text { saturated }\end{array}$ & -0.51 to -1.21 & $\begin{array}{c}\text { aggressive to very } \\
\text { aggressive }\end{array}$ \\
\hline Gilap & Upper-centre & -0.22 to 0.05 & $\begin{array}{c}\text { aggressive to almost } \\
\text { saturated }\end{array}$ & -0.96 to -0.99 & $\begin{array}{c}\text { very aggressive } \\
\text { Ngreneng }\end{array}$ \\
\hline Bribin & Leakage & -0.93 to 0.29 & $\begin{array}{c}\text { aggressive to almost } \\
\text { saturated }\end{array}$ & -0.12 to -1.01 & $\begin{array}{c}\text { aggressive to very } \\
\text { aggressive }\end{array}$ \\
\hline
\end{tabular}

From the above table, it turns out that SI at each cave has a different value. According to its position, on dry and rainy season, the caves at under course (Bribin and Ngreneng Caves) have indices to more constant compared to other caves, and Bribin Cave confirms the most stable PAD. However, the river at Bribin Cave has the most aggressive characteristic during all the year (SI level never exceed the level of zero on rainy season) as Ngreneng's. As a comparison, the SI at upper course, e.g. Gilap Cave, reaches the highest level of SI in dry season at amount of 0.61 . Even on the beginning of dry season, the SI is positive. This indicates that dissolution process has stopped. This reality is found also at Luweng Jomblangan and Pentung River. Conversely, this phenomenon does not appear at under course caves. It indicates that in dry season, the process of cave development is more intensive for upper course caves, while the process of widening tunnel in dissolution process is more intensive for under course caves (SI is negative) as shown by Bribin and Ngreneng Caves, though in rainy season, those processes are affected primarily by conduit flow component.

The distribution level of SI proves that the more intensive mixing process between diffuse and fissure flow comes to pass at under course caves. Ford and Williams (1992), Bogli (1980), Plummer (1975), and Jankowski and Jacobson (1991) state that the mixing between water with high SI to calcite is able to decrease the SI value and causes the water becomes aggressive to dissolve carbonate rock. The previous analysis of PAD illustrates that the under course caves, especially Bribin, have high PAD to cause aggressivity level of Bribin becomes undersaturated in dry season. 


\section{b. The condition of SKD along SBT Bribin}

Daoxian (2005) states that some parameters of karst water quality is able to identify SKD pattern such as: variation of $\mathrm{pH}$; $\mathrm{SI}$; with respect to calcite mineral; carbordioxide partial pressure; and dissolved calcium or bicarbonate that are conducted in karst underground river components, such as (1) rain water as an input; (2) drip water from cave ornament/speleothem as an indicator of dissolution-precipitation processes, and (3) the water of underground river. Table 12 and 13 below present the condition of SKD parameter at SBT Bribin upper and under course. The analysis does not separate rainwater between upper and under course and between dry and rainy season so the different characteristics of SKD parameter between drip water, rainwater, and underground river are known clearly.

Table 12. The Distribution of SKD Parameters of SBT Bribin in Dry Season

\begin{tabular}{|l|c|c|c|c|c|c|}
\hline \multirow{2}{*}{$\begin{array}{c}\text { SKD } \\
\text { PARAMETER }\end{array}$} & \multicolumn{2}{c|}{ UPPER COURSE (GILAP CAVE) } & \multicolumn{2}{c|}{ UNDER COURSE (BRIBIN CAVE) } \\
\cline { 2 - 7 } & RAINWATER & DRIP WATER & UNDERGROUND & RAINWATER & DRIP WATER & $\begin{array}{c}\text { UNDERGROUND } \\
\text { RIVER }\end{array}$ \\
\hline $\mathbf{p H}$ & $6.29-6.55$ & $8.29-8.57$ & $7.06-8.42$ & $6.29-6.55$ & $7.06-7.72$ & $6.96-7.39$ \\
\hline $\mathbf{L O g} \mathbf{P}_{\mathbf{C O} 2}$ & $-1.59--1.87$ & $-3.03--3.31$ & $-1.71--3.09$ & $-1.59--1.87$ & $-1.88--2.47$ & $-1.53--2.13$ \\
\hline $\mathbf{S I} \mathbf{k a l s i t}$ & $-1.77--2.14$ & $0.56-1.25$ & $-0.15-1.18$ & $-1.77--2.14$ & $-0.52-0.29$ & $-0.83-0.26$ \\
\hline $\mathbf{C a}^{2+}(\mathbf{m g} / \mathbf{l t})$ & $14.3-18.8$ & $62.6-80.0$ & $50.56-68.08$ & $14.3-18.8$ & $45.1-92.7$ & $86.13-110.3$ \\
\hline $\mathbf{H C O}_{3}^{-}(\mathbf{m g} / \mathbf{l t})$ & $43.3-53.1$ & $183-248$ & $178-265$ & $43.3-53.1$ & $164-347$ & $242-278$ \\
\hline
\end{tabular}

Table 13. The Distribution of SKD Parameters of SBT Bribin in Wet Season

\begin{tabular}{|l|c|c|c|c|c|c|}
\hline \multirow{2}{*}{$\begin{array}{c}\text { SKD } \\
\text { PARAMETER }\end{array}$} & \multicolumn{2}{c}{ UPPER COURSE (GILAP CAVE) } & \multicolumn{2}{c|}{ UNDER COURSE (BRIBIN CAVE) } \\
& RAINWATER & DRIP WATER & $\begin{array}{c}\text { UNDERGROUND } \\
\text { RIVER }\end{array}$ & RAINWATER & DRIP WATER & $\begin{array}{c}\text { UNDERGROUND } \\
\text { RIVER }\end{array}$ \\
\hline $\mathbf{p H}$ & $6.29-6.55$ & $6.67-7.22$ & $6.52-7.12$ & $6.29-6.55$ & $6.93-7.18$ & $6.46-7.03$ \\
\hline $\mathbf{L O g} \mathbf{P}_{\mathbf{C O} 2}$ & $-1.59--1.87$ & $-1.37--2.00$ & $-1.47--1.95$ & $-1.59--1.87$ & $-1.65--1.98$ & $-1.19--1.79$ \\
\hline SI kalsit & $-1.77--2.14$ & $-0.17--1.10$ & $-0.51--1.31$ & $-1.77--2.14$ & $-0.65--0.79$ & $-0.12--1.79$ \\
\hline $\mathbf{C a}^{2+}(\mathbf{m g} / \mathbf{l t})$ & $14.3-18.8$ & $12.0-57.5$ & $31.8-42.7$ & $14.3-18.8$ & $15.6-41.3$ & $67.7-134.4$ \\
\hline $\mathbf{H C O}_{\mathbf{3}}^{-}(\mathbf{m g} / \mathbf{l t})$ & $43.3-53.1$ & $111-187$ & $110-154$ & $43.3-53.1$ & $148-192$ & $149-300$ \\
\hline
\end{tabular}

Based on the tables above, it appears out that in both dry and rainy season, there is a difference among SKD parameters for drip water and underground river, even when it is compared to SKD parameters for rainwater in Bribin catchment's area. Vesper and White (2004) and Daoxian (2005) explain that scatter plot analysis is used to characterize SKD parameter on many type of water at karst area and to understand the interaction among parameter. Based on scatter plot analysis between SI calcite and log $\mathrm{PCO}_{2}$, SI calcite and log calcium, SI calcite and $\mathrm{pH}$, SI calcite and $\log \mathrm{PCO}_{2}$ in upper and under course caves, on dry and rainy season, it turns out that: 
(1) In dry season, the water aggressiveness condition at upper course of SBT Bribin (Gilap Cave) is mostly on supersaturated condition (the SI is positive). This condition is experienced by both speleothem drip water and underground river. Another characteristic found is high $\mathrm{pH}$ value, low partial $\mathrm{CO}_{2}$ pressure, and high dissolved calcium. The high SI calcite at Gilap Cave has significant correlation with the low $\mathrm{CO}_{2}$ supply from cave tunnel (closed system), since it is already used on dissolution process within unsaturated zone. Additionally, Gilap Cave also performs strong correlation between the high SI calcite with $\mathrm{pH}$ and dissolved calcium. The dominant hydrogeochemical process is water-rock interaction (precipitation of calcite mineral) to develop cave speleothem, intensively.

(2) The aggressivity condition at under course of SBT Bribin tends to be aggressive and undersaturated (negative SI). The $\mathrm{pH}$ value on this area is low in dry season with a slight fluctuation. The value of partial $\mathrm{CO} 2$ pressure is much higher than it of Gilap Cave. It shows that the open system of karst aquifer causes the water becomes aggressive due to the continuous supply of CO2. As a result, the dominant process is calcite dissolution. The widening of the underground river tunnel and the minimum ornament proves this domination of dissolution process.

(3) Due to dilution by precipitation in rainy season, the aggressiveness of water at upper and under course experience a declining SI to undersaturated condition that causes a domination of dissolution and widening of karst channel. The aggressiveness condition at Bribin Cave is higher than Gilap's, nevertheless; the same phenomenon is also experienced by some parameters, i.e the addition of $\mathrm{CO}_{2}$ from conduit flow, the decline of $\mathrm{pH}$ and dissolved calcium. Another process to contribute dissolution process are: mixing between drip water and underground river water and strong $\mathrm{CO}_{2}$ diffusion at under course caves due to the open system to occur. The concept of aggressiveness condition and SKD parameter of Bribin underground river on upper and under course are illustrated in Figure 2 and 3. 


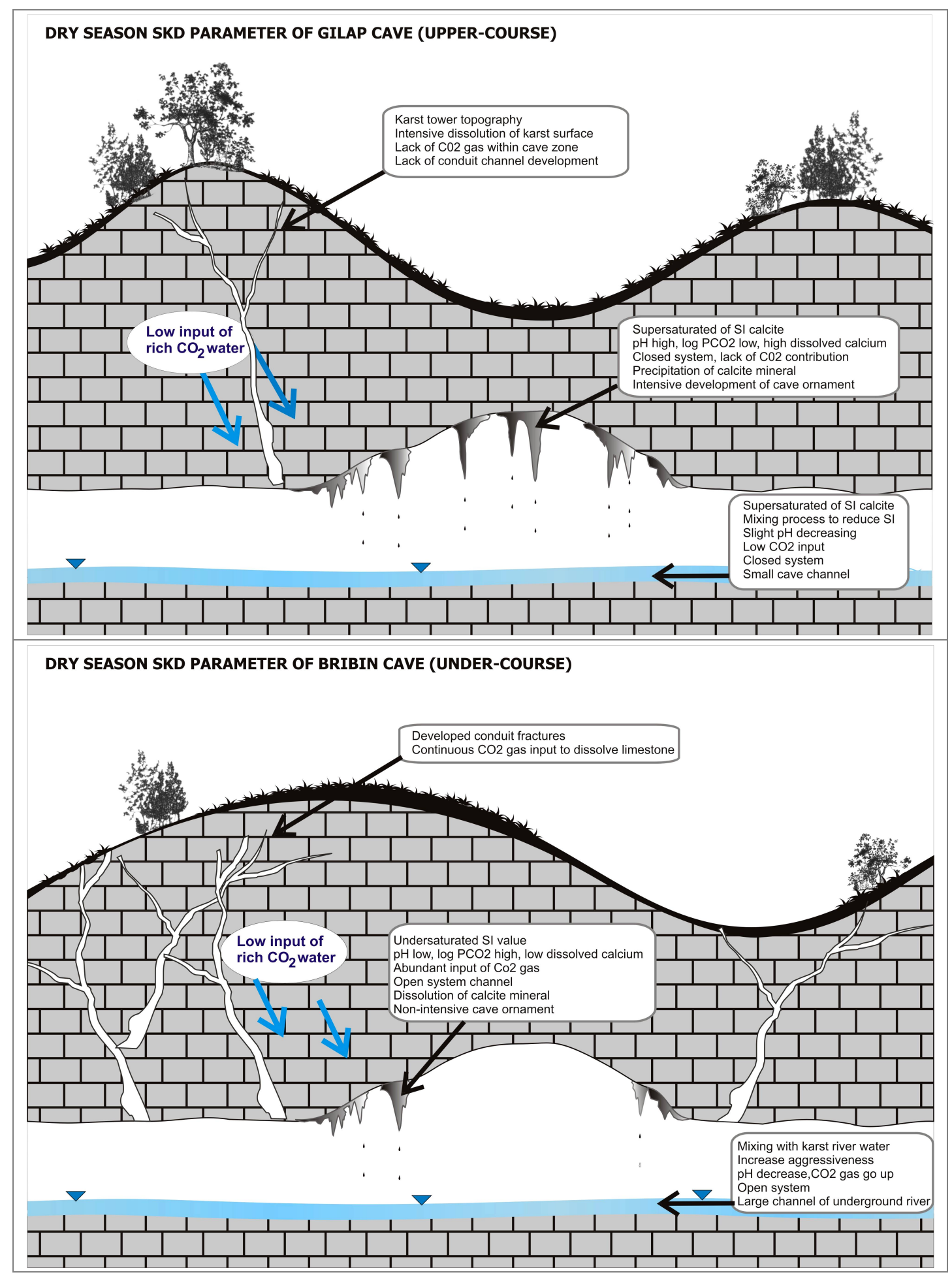

Figure 2. Karst Water Aggressiveness Conceptual Model of SBT Bribin in Dry Season 


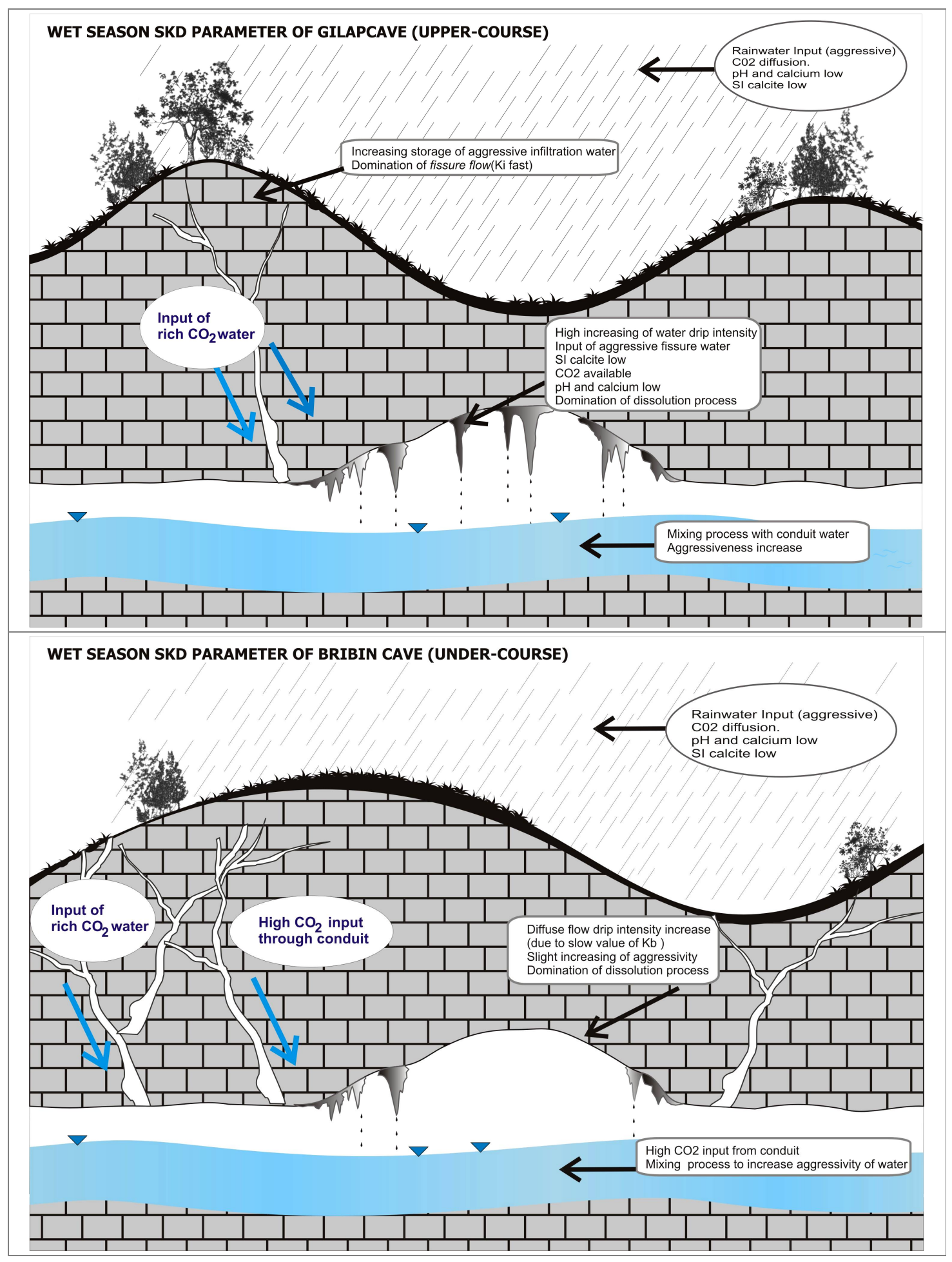

Figure 3. Karst Water Aggressiveness Conceptual Model of SBT Bribin in Wet Season 


\section{Conclusion}

1. The highest PAD is found at Bribin Cave (under-course) due to its aquifer character to release diffuse flow component very slowly. Meanwhile, Gilap Cave (uppercourse) performs the development of fissure fractures with PAD value lesser compare to under-course cave. In flood events, the significant PAD confirmed in Ngreneng Cave, subsequent to its smallest $K_{c}$ value.

2. Bribin Cave (under-course) performs the strongest correlation between PAD and dissolved chemical constituent due to its largest PAD. In consequences, water-rock interaction process is dominant. In wet season, the correlation between PAD and hydrogeochemistry becomes weak as a result of conduit flow contribution, especially takes place in sinkhole caves $\left(K_{c}=f a s t\right)$, such as Ngreneng and Jomblangan Caves.

3. In dry season, Bribin Cave (under-course) performs the most aggressive cave to dissolve carbonate rock, characterized by higher partial pressure of $\mathrm{CO}_{2}$ gas and open-system channel to present. Similar condition also found in Jomblangan Cave as an open-system cave (morphology as a cenote). Another factor to increase aggressiveness is mixing process between conduit and diffuse flow that consequence to reduce the SI value inside the water. On the other hand, the upper-course cave (Gilap Cave) confirms higher value of SI Calcite (low aggressivity) due to the lack of $\mathrm{CO} 2$ gas contribution through the cave channel (closed system). In wet season, all caves confirm decreasing value of SI Calcite (high aggressivity), especially in Ngreneng and Jomblangan Caves, due to their morphology as a sinkhole that always obtained large volume of conduit flow. 